\title{
Social care for homeless children in Ukraine in the 20-30's of the twentieth century
}

\author{
O. Kozlova, O. Bilashenko \\ A. S. Makarenko Sumy State Pedagogical University, Sumy, Ukraine \\ Corresponding author. E-mail: olsumskaya1993@ukr.net
}

Paper received 16.03.20; Accepted for publication 04.04.20.

\section{https://doi.org/10.31174/SEND-PP2020-227VIII91-05}

\begin{abstract}
The essence of the emergence of the social phenomenon of child homelessness in Ukraine in the 20-30's of the twentieth century is revealed in the article. The reasons for overcoming child neglect in Ukraine in the 20-30's of the last century are analyzed, among which are the low living standards of the Ukrainian family, the inaccessibility of the education system for most children, the social-class division, political repression and deportation of Ukrainians. The ways of overcoming child homelessness are identified and the process of forming a network of social educational institutions is considered, among which the main role was given to the orphanage and the children's town. Measures to promote work on child protection and children social upbringing are reflected.
\end{abstract}

Keywords: social care, 20-30 years of the XX century, child homelessness, orphanages, children's towns.

Introduction. Child homelessness is one of the most pressing society problems, which is a natural consequence of socio-economic changes, political conflicts or the spiritual crisis. Nowadays Ukrainian society, aimed at humanizing relationships in the family institution, its negative effects are particularly acute.

Analysis of latest researches and publications. The problem of child homelessness in the 20-30's of the twentieth century was investigated by A.G. Zinchenko, V.E. Vinogradov-Bondarenko, O.S. Paraschevina, N.P. Trupinina, S.E. Luparenko, L.O. Korobova, N.P. Pavlik, N.P. Ditchek, T.V. Filimonov and others. The activities of the small children's town as typical institutions of that period social upbringing were covered in the magazines "Soviet education", "Rillya", "Way of education", etc.

The aim of the article is to reveal the causes of social care for homeless children in the 20-30's of the twentieth century.

Research Methods. Specific search (theoretical analysis, synthesis, systematization of archival documents) and logico-historical analysis (analysis of periodicals) were used to achieve the article aim.

Results. The beginning of the twentieth century in the Ukrainian people history is known to have been marked by a series of political upheavals that claimed the thousands of compatriots' lives. Most of the consequences of the socio-economic crisis have affected children. War, famine, the plight of families led to the fact that some children and adolescents, without homes, supervision, were forced to commit crimes, begging, vagrancy, which caused the emergence of homeless children category. Homeless children - children, who have been abandoned by their parents, have left the family or childcare facilities themselves and have no permanent residence.

According to a contemporary Ukrainian researcher, L. Korobova, in March 1921, there were 9 million children in Ukraine aged 4 to 16 , who needed social assistance, among them from 4 to 8 years $-3,6$ million, from 8 to 16 years $-5,4$ million. In 1923 , the Central Statistical Office published data, according to which in the country there were 8 million children aged from 4 to 15 years, 2 million of them were preschool children age, 4.8 million school age, 500 thousand - half orphans, 250 thousand orphans. According to the People's Commissar, childcare facilities in 1923 covered only 1,65 million children [5].

The main causes of children homelessness in Soviet Ukraine in the 20's - 30's of the XX century should include:

1. Revolution, civil war, epidemics, political repression and deportation of Ukrainians.

2. The poor, the famine, the low material living standard of the majority of the country population, the unemployment that was most prevalent among young people.

3. Disadvantages of developing a new educational system, the actual inaccessibility of the education system for some children;

4. Socio-psychological climate of transitional period, formation of a marginal personality;

5. The social-class policy of the Soviet government and the formation of an authoritarian political system, the crisis of family relations, neglect, half-orphanage, cruel treatment of children, their exploitation [4, p. 18; 1, p. 8].

Custody of socially disadvantaged categories of children has been recognized as one of the priority areas of governmental structures activity of the Soviet state. Thus, in the practice of state bodies activity combating children homelessness the following forms of work have been developed:

1. Selection of homeless children.

2. Placement of adolescents in the boarding schools.

3 . Application of the system of individual and collective patronage.

4. Directing homeless teenagers to study at schools of factory and plant education and factory faculties.

5. Adolescents' employment.

6. Re-evacuation of Russian children.

7. Provision of financial assistance to children from needy families.

8. Carrying out relief campaigns (lotteries, charity performances, "Children Protection Weeks", "Hungry Children's Days", fundraisers and things, etc.).

9. Creation of food outlets and nights for the homeless [2, p.10]

For the Soviet authorities, the main task was to create the educational system and social upbringing that in the short term could eliminate such a phenomenon as children homelessness. In 1920, the People's Commissariat of Education of Ukraine issued a "Declaration on the Children Social Education", in which the orphanage was recog- 
nized as the best form of children upbringing. The Declaration indicated the need to educate children in the spirit of communism, labor education, combination of education and upbringing in one process, the People's Commissariat of Education of the USSR did not take school as a basis, but the social upbringing and recommended orphanages instead of schools [8, p.38].

Assistance to homeless and disadvantaged children was seen as an important part of the country's social agenda. The Soviet government transformed all the orphanages into state ones and transferred them to the People's Commissariat of Social Security under the authority of the People's Commissariat. Implementation of various measures eliminating homelessness has been entrusted to various state bodies. Thus, the People's Commissariat for Health was concerned with eliminating the children homelessness under 4 years; People's Commissariat of Education - eliminating homelessness children aged 4 to 18; The People's Commissariat of Internal Affairs and the State Political Administration fought juvenile offenses and removed them from the streets; The People's Commissariat of Labor and the People's Commissariat of Land Affairs engaged homeless in the employment. Government agencies were assisted by voluntary societies, organizations and trade unions.

The new system of People's Education and upbringing of the USSR envisaged the functioning of a diverse network of social educational institutions. They consisted of: institutions for normal children: orphanage, work school, kindergarten; institutions for disadvantaged children; extracurricular institutions and organizations for the social children upbringing. However, an orphanage was intended to become as the center of social upbringing, the task of which was to "fully realize the ideal of social education". All other this system institutions "had to focus on and approach the orphanage" [7, p. 13]. The People's Commissariat of Education carried out work on the preparation of normative documents regulating the activities of social educational institutions. This is the "Decree on the Implementation of the 7-year Unified Labor School (June 15, 1920); Ordinance on orphanages (16 June 1920); "Resolution on Children's Institutions for Physically Disabled Children (June 18, 1920) and several others [3, p. 31-33].

At the end of 1924, the network of children's institutions in Ukraine included:

- Child care institutions: receivers, manifolds for normal children and juvenile offenders, open children houses, agricultural colonies for the homeless and underage delinquents and orphanages for juvenile delinquents;

- institutions of normal childhood: urban and rural labor schools, orphanages, day orphanages, children's towns and children's kindergartens;

- institutions of defective childhood: primary and secondary orphanages for mentally retarded, blind and deaf children;

- institutions of communist children's movement organization: children's clubs, libraries, summer children's colonies, playgrounds, camps, children's theaters $[6, \mathrm{p}$. 41]

In 1921-1922 a mass movement of children to the south of the regions of the hungry Volga region was observed in Ukraine; children affected by the civil war. Under such conditions, the authorities initiated a massive orphanages' opening, where children could receive food and medical care. As a rule, most of these establishments were located in rural areas (with an agricultural slope) or in resort towns where educational, economic and production facilities were combined into a single system.

During the 1920s and 1930s, government agencies took actions in the fight against child homelessness, however such work forms as removing the homeless from the street and placing them in boarding schools; use of system of individual and collective patronage; the direction of homeless teenagers to study at factory and plant schools and their employment; one-off relief campaigns (lotteries, charity shows, "helping weeks", fundraising money and things, etc.); setting up food and nights for needy children; patronage of labor collectives over boarding schools, providing them financial assistance; conducting social and preventive work were used.

One of the work forms with homeless children was the creation of children's towns. As a rule, they are located on the city outskirts or in the countryside. Children's towns had several buildings in which children of different ages (preschoolers, younger students, teenagers) lived separately. Various educational activities were carried out in the towns with the children, new pedagogical ideas were actively introduced, and the children were ideologically trained. An important role in the children's towns life was played by agriculture or the production of various goods, as the towns were partly self-sufficient.

During the study period, a large number of homeless children, who were covered by the social educational system, were removed from the streets thanks to the children's towns. Thus, in the 1920s-1930s, unique facilities for children were established in the territory of the USSR combating child homelessness.

Conclusions. Therefore, the main causes of child homelessness include - socio-economic, political, psychological. Combating child homelessness in the 1920s and 1930s was recognized as the main activity of government and non-governmental organizations. Despite the events the First World War I and the famine, the authorities managed to strengthen their positions in the social sphere. Social education in Ukraine differed in its focus on the overall organization of childhood, the arrangement of the collective life of the child population. Within a short period of time, a network of social care institutions was built, where children were able to stay permanently. Children's camps in the social education system have played an extremely important role: they have provided shelter to hundreds of homeless children, created the conditions for comprehensive harmonious development of adolescents, carried out practical preparation of children for life. 


\section{REFERENCES}

1. Vinogradova-Bondarenko, V. (2001). Education of homeless children in Ukraine in the 20-s of the twentieth century : author's abstract. diss. for the sciences. degree of Cand. ped. Sciences: Special. 13.00.01 "General Pedagogy and History of Pedagogy". Kyiv. 23.

2. Dyushen, V.M. (1926). Target installation of children's homes, children's towns and children's colonies. The path of education. 7.9 - 14.

3. Collection of decrees and orders on the People's Commissariat of Education of the USSR. I. 60.

4. Zinchenko, A.G. (2002). Children's homelessness in Soviet Ukraine in the 20's first half of the 30's of the twentieth century: author's abstract. diss. for the sciences. degree of cand. hist. sciences: Special. 07.00.01 "History of Ukraine". Odessa. 25.

5. Korobova, L.O. (2012). The place of the child in the system of social education of Ukraine (20-s - early 30-s.). Retrieved from: http://dspace.udpu.org.ua:8080/jspui/handle/6789/1496

6. A guide to social education (1924). 4 ed. Kh.: State Publishing House of Ukraine. 312.

7. Siropolko, S. (1934). National education in Soviet Ukraine. Warsaw. 240.

8. Filimonova T. (2009). On the Question of the Activity of Children's Towns in Ukraine (1920's). The path of education. 1. $37-42$. 